\title{
Integration of Some Bio Compounds with Compost Tea to Produce Sweet Corn without Mineral Fertilizers
}

\author{
Saad Abou-El-Hassan ${ }^{1}$ and Heba S. El-Batran ${ }^{2}$ \\ ${ }^{1}$ Central Lab of Organic Agriculture, Agricultural Research Center, Egypt. \\ ${ }^{2}$ Agricultural and Biological Research Division, National Research Centre, 33 El Buhouth St, Dokki, \\ Giza, P.O. 12622, Egypt.
}

Received: 25 July 2020 / Accepted 05 Sept. August 2020 / Publication date: 30 Sept. 2020

\begin{abstract}
A field experiment was designed at the Dokki site for Protected Agriculture, Ministry of Agriculture and Land Reclamation, Giza, Egypt, during two successive seasons of 2017 and 2018. This experiment aims to improve the efficiency of compost tea by adding some bio compounds for producing sweet corn (Meilan F1 Hybrid) without mineral fertilizers. The treatments of compost tea only, compost tea enriched with extracts of algae, azolla or yeast were compared to recommended mineral fertilizers. Applying compost tea enriched with yeast extract gave the highest vegetative growth, yield and ear properties of sweet corn with no significant differences compared to use mineral fertilizers. The application of compost tea enriched with extracts of algae or azolla reduced growth, yield and ear characteristics of sweet corn compared to mineral fertilizer. The treatments of compost tea enriched with extracts of algae, azolla or yeast were superior to non enriched compost tea in all studied traits. This study illustrated the possibility of utilizing algae, azolla and yeast extracts to improve the efficiency of compost tea to produce a good yield and quality of sweet corn without mineral fertilizers.
\end{abstract}

Keywords: sweet corn, compost tea, algae extract, azolla extract, yeast extract.

\section{Introduction}

Sweet corn (Zea mays var. rugosa) is an increasingly popular vegetable for consumption in many countries i.e. Australia, Canada, USA, Europe, Japan and South-East Asia. Sweet corn has high sugar content in the early dough stage, where the sugars accumulate in the kernels two or three times more than the normal maize (Doehlert et al., 1993). Sweet corn is a very profitable crop for farmers because it is harvested after short time as $65-90$ days depending on the cultivars and has a high price for local market and exportation. Economic value of sweet corn might be double when it is organically produced due to increased consumer demand and limited product availability (Fahrurrozi et al., 2016).

Generally, vegetables or crops produced using organic fertilizers are more attractive to the consumer than those produced using inorganic fertilizers. This is due to its free of synthetic chemicals that harm the environment and human health (Yusuff et al., 2007). Use of compost has a positive effect on the physical and biological properties of the soil. However, compost cannot be relied upon as the sole source of crop nutrition because the high application of compost may cause plant toxicity, due to its high micronutrient content (Prabhat, 1999). Applying compost by the suitable amount simultaneously before planting, leads to the nutrients released from compost are insufficient for crop requirements. Adding compost tea during the growing season can provide organic crops with the rest of their nutrient requirements (Gross et al., 2008; Abou-El-Hassan et al., 2014).

Compost tea is one sources of plant nutrition which is prepared by fermenting compost in water for a period of time in order to extract soluble organic matter, beneficial microorganisms and nutrients in the watery solution (Kelley, 2004; Scheuerell and Mahaffee, 2004). Compost tea can be produce using different methods, either is adding aerating, means active aerated extract or not, means passive aerated extract. Compost tea is rich of nutrients, organic compounds and beneficial microbes that positively effect on the plant rhizosphere, besides improves soil physical and chemical properties as well as suppress some plant pathogens. It has beneficial effects on plant growth and considered as a soil amendment (Abbasi et al., 2002; Biocycle, 2004; Gharib et al., 2008; Meshref et al., 2010). The

Corresponding Author: Saad Abou-El-Hassan, Central Lab of Organic Agriculture, Agricultural Research Center, Egypt. E-mail: saad0777@yahoo.com 
additives of compost tea can be added at the beginning or during the fermentation process, with the intention to enhance the microbial population and raise the efficiency of compost tea (Ingham, 2005). Molasses, fish hydrolysate, rock dust, seaweed, kelp, humic acid and yeast extract are common substrates used in the production and stability of compost tea (Scheuerell and Mahaffee, 2004; Ezz ElDin and Hendawy, 2010; Naidu, et al., 2010).

Algae extract is a rich of macro and micro elements, nature hormones like Auxins, Gibberellins and Cytokinin which induce cell division and increasing cell enlargement and lead to balance of physiological and biological processes and increasing photosynthesis processes and improving growth characters (Jensen, 2004). Application of algae extract leads to the production of plants vigor growth, higher nutrient uptake, more tolerant of stress conditions, better in the productivity and yield quality (Norrie and Keathley, 2006; Khan et al., 2009; Abd El-Motty et al., 2010; Sarhan et al., 2011).

Azolla in symbiosis with cyanobacterium (Anabaena azollae) can fix 2-4 $\mathrm{kg} \mathrm{N}$ ha/day, releasing the nutrients and growth promoting substances like gibberellins, cytokinins, auxins, abscisic acid, vitamins, antibiotics and amino acids into soil in an easily available form to plants (Wagner, 1997; EL-Zeky et al., 2005; Bindhu, 2013; EL Shimi et al., 2015; Hanafy and El-Emery, 2018).

Yeast extract is a rich of nitrogen, it produces beneficial substances like growth regulators (especially cytokinins), amino acids and vitamins (especially B-complex) that work to improve the plant cell division and its growth that enhance plant growth and productivity (Amer, 2004; El-Tohamy et al., 2008; Mahmoud et al., 2013; Abdelaal et al., 2017).

Therefore, this study investigates the possibility of utilizing algae, azolla and yeast extracts to improve the efficiency of compost tea to produce sweet corn without mineral fertilizers.

\section{Materials and Methods}

Field experiment on sweet corn was carried out at the Dokki site for Protected Agriculture, Ministry of Agriculture and Land Reclamation, Giza, Egypt, during two summer seasons of 2017 and 2018. This experiment was performed to improve the efficiency of compost tea by adding some bio compounds for producing sweet corn without mineral fertilizers.

\section{Plant Material}

Seeds of sweet corn (Meilan F1 Hybrid) were planted in the field on the first week of May in both seasons. The experimental area was prepared into ridges after plowing and leveling; each plot contained three ridges of $0.6 \mathrm{~m}$ width and $3 \mathrm{~m}$ length. The seeds were planted at a distance of $0.25 \mathrm{~m}$ in one row on ridge. The plants were three times a week using drip hoses (flow rate $41 / \mathrm{h}$ ); physical and chemical properties of the experimental soil were presented in Table 1 . The experiment was designed in complete randomized blocks with three replicates. The plot area was $6 \mathrm{~m}^{2}(3 \mathrm{~m}$ length and 2 m width).

Table 1: Physical and chemical properties of the experimental soil

\begin{tabular}{|c|c|c|c|c|c|c|c|c|c|c|c|c|}
\hline \multirow{2}{*}{$\begin{array}{c}\text { Clay } \\
\%\end{array}$} & \multirow{2}{*}{$\begin{array}{c}\text { Silt } \\
\%\end{array}$} & \multirow{2}{*}{$\begin{array}{c}\text { Sand } \\
\%\end{array}$} & \multirow{2}{*}{ Texture } & \multirow{2}{*}{$\mathbf{p H}$} & \multirow{2}{*}{$\begin{array}{c}\text { EC } \\
\mathrm{dS} / \mathrm{m}\end{array}$} & \multicolumn{4}{|c|}{ Cations meq/l } & \multicolumn{3}{|c|}{ Anions meq/l } \\
\hline & & & & & & $\mathrm{Ca}^{++}$ & $\mathbf{M g}^{++}$ & $\mathrm{Na}^{+}$ & $\mathbf{K}^{+}$ & $\mathrm{HCO}_{3}{ }^{-}$ & $\mathrm{Cl}^{-}$ & $\mathrm{SO}_{4}=$ \\
\hline 47.94 & 40.61 & 11.45 & Silt clay & 7.76 & 1.03 & 2.12 & 1.15 & 4.53 & 1.54 & 2.27 & 4.75 & 2.83 \\
\hline
\end{tabular}

2. The Experimental Treatments

1- Mineral fertilizer as N, P and K (control)

2- Compost tea (CT)

3- Compost tea enriched with algae extract $(\mathrm{CT}+$ Algae $)$

4- Compost tea enriched with azolla extract (CT + Azolla)

5- Compost tea enriched with yeast extract $(\mathrm{CT}+$ Yeast $)$

\section{Quantities of application}

The control treatment was a mineral fertilizers of N, P and K as follow $80 \mathrm{~kg} \mathrm{~N} / \mathrm{fed}$. as $390 \mathrm{~kg}$ ammonium sulphate $(20.5 \% \mathrm{~N}), 26 \mathrm{~kg} \mathrm{P}_{2} \mathrm{O}_{5} /$ fed. as $168 \mathrm{~kg}$ calcium super phosphate $\left(15.5 \% \mathrm{P}_{2} \mathrm{O}_{5}\right)$ and 
$40 \mathrm{~kg} \mathrm{~K}_{2} \mathrm{O} / \mathrm{fed}$. as $83 \mathrm{~kg}$ potassium sulphate $\left(48 \% \mathrm{~K}_{2} \mathrm{O}\right)$. Commercial compost was used to prepare all types of compost tea. The properties of used compost are showed in Table 2.

Table 2: Analyses of the used compost

\begin{tabular}{|c|c|c|c|c|c|c|c|c|c|c|c|c|}
\hline \multirow{2}{*}{$\begin{array}{l}\mathrm{pH} \\
1: 5\end{array}$} & \multirow{2}{*}{$\begin{array}{c}\text { EC 1:10 } \\
\text { dS } / \mathbf{m}\end{array}$} & \multirow{2}{*}{$\begin{array}{l}\text { O.M } \\
(\%)\end{array}$} & \multirow{2}{*}{$\begin{array}{c}\text { C/N } \\
\text { Ratio }\end{array}$} & \multicolumn{5}{|c|}{ Macro elements (\%) } & \multicolumn{4}{|c|}{ Micro elements (ppm) } \\
\hline & & & & $\mathbf{N}$ & $\mathbf{P}$ & $\mathbf{K}$ & $\mathrm{Ca}$ & Mg & $\mathrm{Fe}$ & $\mathbf{Z n}$ & Mn & $\mathbf{C u}$ \\
\hline 8.32 & 4.12 & 28.33 & 17.8 & 1.15 & 0.67 & 1.17 & 0.36 & 0.67 & 244 & 68 & 93 & 13 \\
\hline
\end{tabular}

\section{Preparation of compost tea types}

Concentrated solution of compost tea was prepared by soaking $10 \mathrm{~L}$ compost in $50 \mathrm{~L}$ of water without chlorine (at rate 1:5) for three days with air pumping continuously during the period of soaking by an air pump then was filtrated by plastic net. The same procedures were followed to prepare concentrated solutions of different types of enriched compost tea with adding $100 \mathrm{ml}$ of algae, azolla or yeast extracts at the beginning of compost soaking. Spirulina algae extract produced by the Soil, Water and Environmental Research Institute was used. Azolla extract was prepared by grinding fresh azolla in a blender. Yeast extract was prepared by adding $20 \mathrm{~g}$ of dry yeast with $20 \mathrm{ml}$ of molasses and adding water to a volume of $100 \mathrm{ml}$; these ingredients were transported to a non-sealed liter container and left for 12 hours. All concentrated compost tea types were diluted by water without chlorine at rate 1:10 according to El-Shinawy et al. (1999) and Abou-El-Hassan (2010). The main chemical and microbiological properties of concentrated solutions of different types of compost tea are illustrated in Table 3.

Table 3: The main chemical and microbiological properties of concentrated compost tea (CT) types

\begin{tabular}{lcccc}
\hline Item & CT & CT + Algae & CT + Azolla & CT + Yeast \\
\hline $\mathbf{p H}$ & 8.43 & 8.45 & 8.42 & 8.02 \\
$\mathbf{E c}(\mathbf{d s} / \mathbf{m})$ & 5.14 & 5.55 & 5.58 & 5.65 \\
$\mathbf{N}(\mathbf{m g} / \mathbf{l})$ & 40.88 & 65.52 & 50.12 & 74.76 \\
$\mathbf{P}(\mathbf{m g} / \mathbf{l})$ & 16.36 & 26.91 & 33.81 & 39.66 \\
$\mathbf{K}(\mathbf{m g} / \mathbf{l})$ & 12.26 & 17.23 & 27.52 & 27.75 \\
Fe (mg/l) & 1.45 & 2.53 & 1.54 & 1.72 \\
Mn (mg/l) & 0.90 & 1.42 & 0.92 & 0.97 \\
Zn (mg/l) & 0.12 & 0.18 & 0.13 & 0.16 \\
\hline Total count (cfu $\left.\mathbf{~ m l}^{-1}\right)$ & & & & \\
Bacteria & $1.6 \times 10^{7}$ & $2.4 \times 10^{7}$ & $2.2 \times 10^{7}$ & $2.8 \times 10^{7}$ \\
Fungi & $3.5 \times 10^{3}$ & $3.3 \times 10^{3}$ & $3.5 \times 10^{3}$ & $3.6 \times 10^{3}$ \\
Actinomycetes & $1.2 \times 10^{5}$ & $3.2 \times 10^{5}$ & $1.6 \times 10^{5}$ & $3.7 \times 10^{5}$ \\
\hline
\end{tabular}

\section{Time and Method of Application}

The mineral fertilizers of $\mathrm{N}, \mathrm{P}$ and $\mathrm{K}$ were applied as follow: calcium super phosphate was added as one dose during soil preparation, whereas ammonium sulphate and potassium sulphate were added at three equal portions, after 2, 4 and 6 weeks from planting. All compost tea types were applied to the soil surface weekly at a rate of $1 \mathrm{~L} / \mathrm{m}^{2}$. Compost tea treatments started after one week from sowing seeds and continued for two months.

\section{Data Recorded}

At early dough stage ( 75 to 85 days from planting) the ears were harvested and total yield was recorded for each replicate. Six plants were randomly taken from each replicate for measuring plant growth characters expressed as plant height from soil surface to the highest point of the plant, number of leaves per plant, fresh weight of plant and stem diameter, as well as chlorophyll reading in the fourth upper leaf was recorded by using Minolta Chlorophyll Meter SPAD 501. Nutrient content (N, P 
and $\mathrm{K}$ ) in sweet corn plants were determined in dry matter of the fourth upper leaf according to Cottenie et al. (1982). Total nitrogen, phosphorus and potassium were determined by Micro Kjeldahl, Spectrophotometer and Flame photometer respectively according to FAO (1980). Ten ears from each plot were taken randomly at harvest to measure ear parameters as weight, length and diameter of ear. Samples of ear kernels were randomly bulked from each experimental unit to determine kernel compositions of total sugars, total soluble solids (TSS) and dry matter directly after harvest. Total sugars were determined using the procedures of Association of Official Analytical Chemists (AOAC, 2005). Total soluble solids percentages were read by hand digital refractometer.

\section{Statistical analysis}

Data of the two seasons were arranged and statistically analyzed by the analysis of variances according to Snedecor and Cochran (1980) with SAS software, version 2004. Treatment means were compared using Tukey test at significance level 0.05 .

\section{Results and Discussion}

Effect of different treatments on growth characteristics of sweet corn in both seasons are illustrated in Table 4 and 5. Results showed that the treatments of mineral fertilizers and compost tea enriched with yeast extract gave the highest values in all growth characteristics of plants compared to other treatments. The lowest values in all growth characteristics were resulted from compost tea treatment, while treatments of compost tea enriched with algae or azolla extracts were moderated. Enhancement in the growth of sweet corn plants with using compost tea enriched with yeast extract may be due to the role of yeast extract in improving the efficiency of compost tea as plant nutrition (Ezz El-Din and Hendawy, 2010; Naidu et al., 2010).

Table 4: Effect of treatments on vegetative growth characteristics of sweet corn plants during 2017 and 2018 seasons

\begin{tabular}{lcccccc}
\hline & \multicolumn{2}{c}{ Plant height $(\mathbf{c m})$} & \multicolumn{2}{c}{ Leaf No } & \multicolumn{2}{c}{ Plant weight (kg) } \\
\cline { 2 - 8 } Treatments & $\begin{array}{c}\mathbf{1}^{\text {st }} \\
\text { season }\end{array}$ & $\begin{array}{c}\mathbf{2}^{\text {nd }} \\
\text { season }\end{array}$ & $\begin{array}{c}\mathbf{1}^{\text {st }} \\
\text { season }\end{array}$ & $\begin{array}{c}\mathbf{2}^{\text {nd }} \\
\text { season }\end{array}$ & $\begin{array}{c}\mathbf{1}^{\text {st }} \\
\text { season }\end{array}$ & $\begin{array}{c}\mathbf{2}^{\text {nd }} \\
\text { season }\end{array}$ \\
\hline MF & $197.59 \mathrm{a}$ & $200.92 \mathrm{a}$ & $15.33 \mathrm{a}$ & $15.67 \mathrm{a}$ & $0.953 \mathrm{a}$ & $0.960 \mathrm{a}$ \\
Compost tea & $175.08 \mathrm{~d}$ & $176.59 \mathrm{~d}$ & $12.17 \mathrm{c}$ & $12.17 \mathrm{c}$ & $0.683 \mathrm{~d}$ & $0.723 \mathrm{c}$ \\
CT + Algae & $188.52 \mathrm{bc}$ & $190.33 \mathrm{bc}$ & $14.17 \mathrm{~b}$ & $14.33 \mathrm{~b}$ & $0.853 \mathrm{~b}$ & $0.867 \mathrm{~b}$ \\
CT + Azolla & $183.54 \mathrm{c}$ & $186.87 \mathrm{c}$ & $13.50 \mathrm{~b}$ & $14.00 \mathrm{~b}$ & $0.790 \mathrm{c}$ & $0.813 \mathrm{~b}$ \\
$\mathbf{C T}+$ Yeast & $194.41 \mathrm{ab}$ & $196.67 \mathrm{ab}$ & $15.17 \mathrm{a}$ & $15.83 \mathbf{a}$ & $0.943 \mathrm{a}$ & $0.957 \mathrm{a}$ \\
\hline
\end{tabular}

Means followed in same column by similar letters are not statistically different at 0.05 level according to Tukey test.

MF = Mineral fertilizers $\quad$ CT + Algae $=$ Compost tea enriched with algae extract

$\mathbf{C T}+$ Azolla $=$ Compost tea enriched with azolla extract $\quad \mathbf{C T}+$ Yeast $=$ Compost tea enriched with yeast extract

Table 5: Effect of treatments on vegetative growth characteristics of sweet corn plants during 2017 and 2018 seasons

\begin{tabular}{lcccc}
\hline \multirow{2}{*}{ Treatments } & \multicolumn{2}{c}{ Stem diameter $(\mathbf{c m})$} & \multicolumn{2}{c}{ Chlorophyll (SPAD) } \\
\cline { 2 - 5 } & $\begin{array}{c}\mathbf{1}^{\text {st }} \\
\text { season }\end{array}$ & $\begin{array}{c}\mathbf{2}^{\text {nd }} \\
\text { season }\end{array}$ & $\begin{array}{c}\mathbf{1}^{\text {st }} \\
\text { season }\end{array}$ & $\begin{array}{c}\mathbf{2}^{\text {nd }} \\
\text { season }\end{array}$ \\
\hline MF & $3.767 \mathrm{a}$ & $3.833 \mathrm{a}$ & $55.667 \mathrm{a}$ & $56.500 \mathrm{a}$ \\
Compost tea & $3.133 \mathrm{c}$ & $3.267 \mathrm{c}$ & $44.000 \mathrm{~d}$ & $45.667 \mathrm{c}$ \\
CT + Algae & $3.533 \mathrm{~b}$ & $3.600 \mathrm{~b}$ & $50.867 \mathrm{bc}$ & $51.867 \mathrm{~b}$ \\
CT + Azolla & $3.467 \mathrm{~b}$ & $3.533 \mathrm{~b}$ & $48.667 \mathrm{c}$ & $50.000 \mathrm{~b}$ \\
CT + Yeast & $3.783 \mathrm{a}$ & $3.867 \mathrm{a}$ & $54.667 \mathrm{ab}$ & $57.333 \mathrm{a}$ \\
\hline
\end{tabular}

Means followed in same column by similar letters are not statistically different at 0.05 level according to Tukey test.

MF = Mineral fertilizers $\quad$ CT + Algae $=$ Compost tea enriched with algae extract

$\mathbf{C T}+$ Azolla $=$ Compost tea enriched with azolla extract $\quad \mathbf{C T}+$ Yeast $=$ Compost tea enriched with yeast extract 
Where, yeast extract contains high levels of nitrogen, produces beneficial substances like growth regulators (especially cytokinins), amino acids and vitamins (especially B-complex) that work to increase the division and growth of plant cells leading to enhance plant growth (Amer, 2004; ElTohamy et al., 2008; Mahmoud et al., 2013; Abdelaal et al., 2017). It might also be because the enrichment of compost tea with yeast extract has increased the contents of compost tea from nutrients and beneficial microorganisms counts (bacteria and actinomycetes) as shown in Table 3 that have a positive effect by providing nutrients and growth regulators in the rhizosphere zone, besides improving the physical and chemical soil properties (Abbasi et al., 2002, Biocycle, 2004, Gharib et al., 2008 and Meshref et al., 2010).

Data in Table 6 were mentioned that the highest concentrations of $\mathrm{N}$ and $\mathrm{P}$ were found in plants that treated by mineral fertilizers and compost tea enriched with yeast extract followed by compost tea enriched with extract of algae or azolla treatments. While, $\mathrm{K}$ content of plants was the highest with treatments of mineral fertilizers and compost tea enriched with extracts of yeast, algae or azolla with no significant differences among these treatments. On the other hand, the lowest concentrations of N, $\mathrm{P}$ and $\mathrm{K}$ in plants were obtained by non enriched compost tea. The superiority of nutrient contents in plants that treated by compost tea enriched with extract of yeast, algae or azolla over non enriched compost tea might be due to that the addition of these extracts to compost tea during the fermentation process enhancing the efficiency of compost tea (Ingham, 2005). Where, algae extract is a rich of macro and micro elements, nature hormones which induce cell division and increasing cell enlargement (Jensen, 2004). Besides, azolla in symbiosis with cyanobacterium (Anabaena azollae) can fixing 2-4 $\mathrm{kg} \mathrm{N}$ ha-1day, producing the nutrients and growth promoting substances, vitamins, antibiotics and amino acids (Wagner, 1997; EL-Zeky et al., 2005; Bindhu, 2013; EL Shimi et al., 2015; Hanafy and El-Emery, 2018). As well as, yeast extract contains high levels of nitrogen, produces beneficial substances like growth regulators, amino acids and vitamins (Amer, 2004; ElTohamy, et al., 2008; Mahmoud et al., 2013; Abdelaal et al., 2017). All these beneficial substances are released into compost tea during the fermentation process, resulting in improved of plant growth and nutrient absorption.

Table 6: Effect of treatments on nutritional status of sweet corn plants during 2017 and 2018 seasons

\begin{tabular}{lccccccc}
\hline \multirow{2}{*}{ Treatments } & \multicolumn{2}{c}{$\mathbf{N}$} & \multicolumn{3}{c}{$\mathbf{P}$} & \multicolumn{3}{c}{$\mathbf{K}$} \\
\cline { 2 - 8 } & $\begin{array}{c}\mathbf{1}^{\text {st }} \\
\text { season }\end{array}$ & $\begin{array}{c}\mathbf{2}^{\text {nd }} \\
\text { season }\end{array}$ & $\begin{array}{c}\mathbf{1}^{\text {st }} \\
\text { season }\end{array}$ & $\begin{array}{c}\mathbf{2}^{\text {nd }} \\
\text { season }\end{array}$ & $\begin{array}{c}\mathbf{1}^{\text {st }} \\
\text { season }\end{array}$ & $\begin{array}{c}\mathbf{2}^{\text {nd }} \\
\text { season }\end{array}$ \\
\hline MF & $2.699 \mathrm{a}$ & $2.705 \mathrm{a}$ & $0.353 \mathrm{a}$ & $0.362 \mathrm{a}$ & $2.377 \mathrm{a}$ & $2.384 \mathrm{a}$ \\
Compost tea & $1.854 \mathrm{c}$ & $1.881 \mathrm{c}$ & $0.239 \mathrm{c}$ & $0.241 \mathrm{c}$ & $1.261 \mathrm{~b}$ & $1.267 \mathrm{c}$ \\
CT + Algae & $2.474 \mathrm{~b}$ & $2.503 \mathrm{~b}$ & $0.325 \mathrm{~b}$ & $0.334 \mathrm{~b}$ & $2.270 \mathrm{a}$ & $2.316 \mathrm{~b}$ \\
CT + Azolla & $2.444 \mathrm{~b}$ & $2.497 \mathrm{~b}$ & $0.346 \mathrm{a}$ & $0.352 \mathrm{ab}$ & $2.310 \mathrm{a}$ & $2.345 \mathrm{ab}$ \\
CT + Yeast & $2.625 \mathrm{a}$ & $2.673 \mathrm{a}$ & $0.360 \mathrm{a}$ & $0.369 \mathrm{a}$ & $2.343 \mathrm{a}$ & $2.363 \mathrm{ab}$ \\
\hline
\end{tabular}

Means followed in same column by similar letters are not statistically different at 0.05 level according to Tukey test.

MF = Mineral fertilizers CT + Algae = Compost tea enriched with algae extract

$\mathbf{C T}+$ Azolla $=$ Compost tea enriched with azolla extract $\mathbf{C T}+$ Yeast $=$ Compost tea enriched with yeast extract

Effects of different treatments on yield and ear characteristics of sweet corn in both seasons are presented in Table 7 and 8. The results mentioned that treatment of compost tea enriched with yeast extract produced a yield similar to the yield produced by mineral fertilizers without significant differences between them. Both treatments produced the highest yield per plant and plot as well as gave the best ear characteristics compared to other treatments. The treatment of compost tea enriched with extracts of algae or azolla came in second order, whereas the treatment of non enriched compost tea produced the lowest values of yield and ear characteristics. The superior treatments of compost tea enriched with extract of yeast, algae or azolla over non enriched compost tea can be attributed to its superiority in stimulating vegetable growth of plants as shown in Table 4 and 5, resulting in an increase in photosynthesis and better carbohydrate construction, thus improved yield and ear characteristics of sweet corn. These results are consistent with those obtained by Khan et al. (2009) and Sarhan et al. (2011) on algae extract, Bindhu (2013), EL Shimi et al. (2015), Hanafy and El- 
Emery (2018) on azolla extract, Amer (2004), El-Tohamy et al. (2008), Mahmoud et al. (2013) and Abdelaal et al. (2017) on yeast extract. They mentioned that application of algae, azolla or yeast extracts lead to the production of plants vigor growth, higher nutrient uptake, more tolerant of stress conditions, better in the productivity and yield quality.

Table 7: Effect of treatments on yield component of sweet corn plants during 2017 and 2018 seasons

\begin{tabular}{|c|c|c|c|c|c|c|}
\hline \multirow{2}{*}{ Treatments } & \multicolumn{2}{|c|}{$\begin{array}{c}\text { Yield/plant } \\
\text { kg }\end{array}$} & \multicolumn{2}{|c|}{$\begin{array}{c}\text { Yield/plot }\left(6 \mathrm{~m}^{2}\right) \\
\mathrm{kg}\end{array}$} & \multicolumn{2}{|c|}{$\begin{array}{l}\text { Yield } \\
\text { t/fed. }\end{array}$} \\
\hline & $\begin{array}{c}1^{\text {st }} \\
\text { season } \\
\end{array}$ & $\begin{array}{c}2^{\text {nd }} \\
\text { season } \\
\end{array}$ & $\begin{array}{c}1^{\text {st }} \\
\text { season }\end{array}$ & $\begin{array}{c}2^{\text {nd }} \\
\text { season }\end{array}$ & $\begin{array}{c}1^{\text {st }} \\
\text { season }\end{array}$ & $\begin{array}{c}2^{\text {nd }} \\
\text { season }\end{array}$ \\
\hline MF & $0.493 \mathrm{a}$ & $0.494 \mathrm{a}$ & $13.607 \mathrm{a}$ & $13.637 \mathrm{a}$ & $9.527 \mathrm{a}$ & $9.547 \mathrm{a}$ \\
\hline Compost tea & $0.394 \mathrm{c}$ & $0.399 \mathrm{c}$ & $10.810 \mathrm{~d}$ & $10.930 \mathrm{c}$ & $7.567 \mathrm{~d}$ & $7.650 \mathrm{c}$ \\
\hline CT + Algae & $0.458 \mathrm{~b}$ & $0.466 \mathrm{~b}$ & $12.927 \mathrm{~b}$ & $13.143 \mathrm{~b}$ & $9.050 \mathrm{~b}$ & $9.203 \mathrm{~b}$ \\
\hline CT + Azolla & $0.450 \mathrm{~b}$ & $0.461 \mathrm{~b}$ & $12.690 \mathrm{c}$ & $13.000 \mathrm{~b}$ & $8.883 \mathrm{c}$ & $9.100 \mathrm{~b}$ \\
\hline CT + Yeast & $0.486 \mathrm{a}$ & $0.488 \mathrm{a}$ & $13.530 \mathrm{a}$ & $13.600 \mathrm{a}$ & $9.467 \mathrm{a}$ & $9.520 \mathrm{a}$ \\
\hline
\end{tabular}

Means followed in same column by similar letters are not statistically different at 0.05 level according to Tukey test.

MF = Mineral fertilizers CT + Algae = Compost tea enriched with algae extract

$\mathbf{C T}+$ Azolla $=$ Compost tea enriched with azolla extract $\quad$ CT + Yeast $=$ Compost tea enriched with yeast extract

Table 8: Effect of treatments on the characteristics of sweet corn ears during 2017 and 2018 seasons

\begin{tabular}{|c|c|c|c|c|c|c|}
\hline \multirow{2}{*}{ Treatments } & \multicolumn{2}{|c|}{$\begin{array}{c}\text { Ear weight } \\
\text { g } \\
\end{array}$} & \multicolumn{2}{|c|}{$\begin{array}{c}\text { Ear length } \\
\mathrm{cm}\end{array}$} & \multicolumn{2}{|c|}{$\begin{array}{c}\text { Ear diameter } \\
\mathrm{cm}\end{array}$} \\
\hline & $\begin{array}{c}1^{\text {st }} \\
\text { season }\end{array}$ & $\begin{array}{c}2^{\text {nd }} \\
\text { season }\end{array}$ & $\begin{array}{c}1^{\text {st }} \\
\text { season }\end{array}$ & $\begin{array}{c}2^{\text {nd }} \\
\text { season }\end{array}$ & $\begin{array}{c}1^{\text {st }} \\
\text { season }\end{array}$ & $\begin{array}{c}2^{\text {nd }} \\
\text { season }\end{array}$ \\
\hline MF & $0.265 \mathrm{a}$ & $0.266 \mathrm{a}$ & $28.503 \mathrm{a}$ & $28.567 \mathrm{a}$ & $4.525 \mathrm{a}$ & $4.535 \mathrm{a}$ \\
\hline Compost tea & $0.203 \mathrm{~d}$ & $0.205 \mathrm{c}$ & $21.770 \mathrm{~d}$ & $22.147 \mathrm{c}$ & $3.569 \mathrm{c}$ & $3.630 \mathrm{c}$ \\
\hline CT + Algae & $0.237 \mathrm{~b}$ & $0.242 \mathrm{~b}$ & $25.567 \mathrm{~b}$ & $25.997 \mathrm{~b}$ & $4.208 \mathrm{~b}$ & $4.278 \mathrm{~b}$ \\
\hline CT + Azolla & $0.231 \mathrm{c}$ & $0.237 \mathrm{~b}$ & $24.860 \mathrm{c}$ & $25.467 \mathrm{~b}$ & $4.190 \mathrm{~b}$ & $4.292 \mathrm{~b}$ \\
\hline CT + Yeast & $0.260 \mathrm{a}$ & $0.263 \mathrm{a}$ & $28.110 \mathrm{a}$ & $28.457 \mathrm{a}$ & $4.548 \mathrm{a}$ & $4.605 \mathrm{a}$ \\
\hline
\end{tabular}

Means followed in same column by similar letters are not statistically different at 0.05 level according to Tukey test.

MF = Mineral fertilizers CT + Algae = Compost tea enriched with algae extract

$\mathbf{C T}+\mathbf{A z o l l a}=$ Compost tea enriched with azolla extract $\quad \mathbf{C T}+$ Yeast $=$ Compost tea enriched with yeast extract

Data in Table 9 have illustrated the effects of different compost tea treatments on kernel compositions of sweet corn in two seasons. The results indicated that application of mineral fertilizers as well as compost tea enriched of algae, azolla or yeast extracts increased kernel compositions of total sugars, TSS and dry matter compared to non enriched compost tea.

Table 9: Effect of treatments on the composition of sweet corn kernels during 2017 and 2018 seasons

\begin{tabular}{lcccccc}
\hline \multirow{2}{*}{ Treatments } & \multicolumn{2}{c}{$\%$ Total sugars } & \multicolumn{2}{c}{$\%$ TSS } & \multicolumn{2}{c}{$\%$ Dry matter } \\
\cline { 2 - 7 } & $\begin{array}{c}\mathbf{1}^{\text {st }} \\
\text { season }\end{array}$ & $\begin{array}{c}\mathbf{2}^{\text {nd }} \\
\text { season }\end{array}$ & $\begin{array}{c}\mathbf{1}^{\text {st }} \\
\text { season }\end{array}$ & $\begin{array}{c}\mathbf{2}^{\text {nd }} \\
\text { season }\end{array}$ & $\begin{array}{c}\mathbf{1}^{\text {st }} \\
\text { season }\end{array}$ & $\begin{array}{c}\mathbf{2}^{\text {nd }} \\
\text { season }\end{array}$ \\
\hline MF & $13.65 \mathrm{a}$ & $13.71 \mathrm{a}$ & $17.60 \mathrm{a}$ & $17.67 \mathrm{a}$ & $22.42 \mathrm{a}$ & $22.48 \mathrm{a}$ \\
Compost tea & $12.74 \mathrm{c}$ & $12.80 \mathrm{c}$ & $16.37 \mathrm{c}$ & $16.50 \mathrm{c}$ & $22.11 \mathrm{~b}$ & $22.13 \mathrm{~b}$ \\
CT + Algae & $13.32 \mathrm{~b}$ & $13.41 \mathrm{~b}$ & $17.15 \mathrm{~b}$ & $17.32 \mathrm{~b}$ & $22.41 \mathrm{ab}$ & $22.49 \mathrm{a}$ \\
CT + Azolla & $13.51 \mathrm{ab}$ & $13.56 \mathrm{a}$ & $17.40 \mathrm{ab}$ & $17.47 \mathrm{ab}$ & $22.62 \mathrm{a}$ & $22.55 \mathrm{a}$ \\
CT + Yeast & $13.55 \mathrm{a}$ & $13.70 \mathrm{a}$ & $17.47 \mathrm{a}$ & $17.62 \mathrm{a}$ & $22.65 \mathrm{a}$ & $22.65 \mathrm{a}$ \\
\hline
\end{tabular}

Means followed in same column by similar letters are not statistically different at 0.05 level according to Tukey test.
MF
$=$ Mineral fertilizers
$\mathbf{C T}+$ Algae $=$ Compost tea enriched with algae extract

$\mathbf{C T}+$ Azolla $=$ Compost tea enriched with azolla extract $\mathbf{C T}+$ Yeast $=$ Compost tea enriched with yeast extract 
This result may be attributed to the positive role of mineral fertilizers and enriched compost tea in improving vegetable growth (Tables 4,5 ) and nutritive status (Table 6) of sweet corn plants, which led to increase photosynthesis products that translocation to corn kernels. These results are harmony with those reveled by Amer (2004), El-Tohamy et al. (2008), Khan et al. (2009), Sarhan et al. (2011), Bindhu (2013), Mahmoud et al. (2013), EL Shimi et al. (2015) and Abdelaal et al. (2017).

\section{Conclusion}

It could be concluded possibility utilizing algae, azolla and yeast extracts to improve the efficiency of compost tea to produce a good yield and quality of sweet corn without mineral fertilizers.

\section{References}

Abbasi, P.A., J. Al-Dahmani, F. Sahin, H.A.J. Hoitink and S.A. Miller, 2002. Effect of compost amendments on disease severity and yield of tomato in conventional and organic production systems. Plant Dis., 86: 156-161.

Abd El-Motty, Z., F.M. Shahim, H. El-Shiekh and M.M. Abd EL Migeed, 2010. Effect of algae extract and yeast application on growth, nutritional status, yield and fruit quality of Keitte mango trees. Agriculture of Biological Journal American, 1 (3): 421-429.

Abdelaal, K.A.A., Y.M. Hafez, A. El Sabagh, H. Saneoka, 2017. Ameliorative effects of abscisic acid and yeast on morpho-physiological and yield characteristics of maize plant (Zea mays L.) under water deficit conditions. Fresenius Environmental Bulletin, 26(12): 7372-7383.

Abou-El-Hassan S., M.A.A. Abdrabbo and A.H. Desoky, 2014. Enhancing Organic Production of Cucumber by using Plant Growth Promoting Rizobacteria and Compost Tea under Sandy Soil Condition. Research Journal of Agriculture and Biological Sciences, 10(2): 162-169.

Abou-El-Hassan, S., 2010. Studies on using different compost teas as nutrient solutions for cantaloupe production with nutrient film technique. Ph.D. Thesis Fac. Agric. Ain Shams Univ., Egypt.

Amer, S.S.A., 2004. Growth, green pods yield and seeds yield of common bean (Phaseolus vulgaris L.) as affected by active dry yeast, salicylic acid and their interaction. J. Agric. Sci. Mansoura Univ., 29(3): 1407-1422.

AOAC, 2005. Official methods of analysis. 15th ed. Association of Official Agricultural Chemists. $12^{\text {th }}$ Ed., Washengton, D.C., USA.

Bindhu, K.B. 2013. Effect of Azolla extract on growth performance of Pisum sativum. Int. Res. J. Biological Sci., 2(10): 88-90.

Biocycle, 2004. Building a knowledge base for compost tea. J. Composting and Organic Recycling, June, 1-2.

Cottenie, A., M. Verloo, L. Kiekers, G. Velghe and R. Camrbynek 1982. Chemical Analysis of Plants and Soils. Hand Book, 1-63, Ghent, Belgium.

Doehlert, D.C., T.M. Kuo, J.A. Juvik, E.P. Beers and S.H. Duke, 1993. Characteristics of carbohydrate metabolism in sweet corn sugary-1 endosperms. J. Amer. Soc. Hort. Sci., 118(5): 661-666.

EL Shimi, N.M.M,. El.H.M. El-Badawy and H.I. Tolba, 2015. Response of sweet pepper plants to some organic and bio-fertilizers and its effect on fruit yield and quality.

El-Shinawy, M.Z., E.M. Abd-Elmoniem and A.F. Abou-Hadid, 1999. The use of Organic manure for lettuce plants grown under NFT conditions. Acta Hort. 491: 315-318.

El-Tohamy, W.A., H.M. El-Abagy and N.H.M. El-Greadly. 2008. Studies on the effect of putrescine, yeast and vitamin $\mathrm{C}$ on growth, yield and physiological responses of eggplant (Solanum melongena L.) under sandy soil conditions. Australian Journal of Basic and Applied Sciences, 2 (2): 296-300.

EL-Zeky M.M., R.M. El-Shahat, Gh.S. Metwaly and M. Aref-Elham, 2005. Using of cyanobacteria or Azolla as altenative nitrogen source for rice production, J. Agric. Sci. Mansoura Unvi., 30, 5567-5577.

Ezz El-Din, A.E. and S.F. Hendawy, 2010. Effect of dry yeast and compost tea on growth and oil content of Borago Officinalis plant. Res. J. Agric. Biol. Sci. 6: 424-430. 
Fahrurrozi, Z. Muktamar, Dwatmadji, N. Setyowati, S. Sudjatmiko and M.Chozin. Growth and yield responses of three sweet corn (Zea mays L. var. Saccharata) varieties to local-based liquid organic fertilizer, 2016. International Journal on Engineering Information Technology. 6(3):319-323.

FAO 1980. Soil and Plant Analysis. Soils Bulletin 38/2,250P.

Gharib, F.A., L.A. Moussa and O. Massoud, 2008. Effect of compost and bio-fertilizers on growth, yield and essential oil of sweet Marjoram (Majorana hortensis) plant. Int. J. Agric. Biol., 10: 381-387.

Gross, A., R. Arusi, P. Fine and A. Nejidat, 2008. Assessment of extraction methods with fowl manure for the production of liquid organic fertilizers. Bioresource Technology, 99: 327-334.

Hanafy, A. and G.A.E. El-Emery, 2018. Role of azolla pinnata biofertilizer extract in producing healthy tomatoes. Asian J. Research Biochemistry, 3(3): 1-8.

Ingham, E.R., 2005. The Compost Tea Brewing Manual, 5th edition. Soil Foodweb, Incorporated, Corvallis, Oregon.

Jensen, E., 2004. Seaweed; fact or fancy. Published by Moses the Midwest Organic and Sustainable Education. From the broad Caster. 12(3): 164-170.

Kelley, S., 2004. Building a knowledge base for compost tea. BioCycle 45 (6): 30-34.

Khan, W., U.P. Rayirath, S.Subramanian, M.N. Jithesh, P.Rayorath, D.M. Hodges, A.T. Critchley, J.S. Craigie, J. Norrie and B. Prithiviraj, 2009. Seaweed extracts as biostimulants of plant growth and development. J. Plant Growth Regul., 28:386-399.

Mahmoud, A.R., M. EL-Desuki, M.M. Abdel-Mouty, and A.H. Ali, 2013. Effect of compost levels and yeast extract application on the pea plant growth, pod yield and quality. J. App. Sci. Res., 9(1):149-155.

Meshref, H.A., M.H. Rabie, A.M. El-Ghamry and M.A. El-Agamy, 2010. Maximizing utilization of compost addition using foliar compost extract and humic substances in alluvial soil. J. Soil Sci. and Agric. Eng., Mansoura Univ., 1(9): 957-971.

Naidu, Y., S. Meon, J. Kadir and Y. Siddiqui, 2010. Microbial starter for the enhancement of biological activity of compost tea. International Journal of Agriculture and Biology. 12(1):5156.

Norrie, J. and J. P. Keathley. 2006. Benefits of Ascophyllum nodosum marine plant extract applications to Thompson seedless grape production. Acta Hort., 727: 243-247.

Prabhat K. Gupta, 1999. A handbook of soil, fertilizer and manure. Agrobios India, pp: 269-329.

Sarhan, T.Z., S.T. Ali, S.M.S. Rasheed, 2011. Effect of bread yeast and seaweed extracts on Cucumber (Cucumis sativus L.) plant growth, yield and fruit quality. Mesopotamia J. Agric., 39(2): 26-34.

Scheuerell, S.J. and W.F. Mahaffee, 2004. Compost tea as a container medium drench for suppressing seedling damping-off caused by Pythium ultimum. Phytopathology. 94: 1156-1163.

Snedecor, G.W. and W.G. Cochran 1980. Statistical methods. Sixth Edition, Iowa state university press, Ames., Iowa, U.S.A.

Wagner, G.M., 1997. Azolla: A review on its biology and utilization. Bot Rev., 83(1): 1-27.

Yusuff, M.T.M., O.H. Ahmed, W.A.W. Yahaya and N.M.Ab. Majid, 2007. Effect of organic and inorganic fertilizers on nitrogen and potassium uptake and yield of sweet corn grown on an acid soil. American Journal of Agricultural and Biological Science 2(2): 118-122. 